\title{
História e identidade
}

\author{
Tania Regina de Luca
}

DUTRA, Eliana de Freitas. Rebeldes literários da República. História e identidade nacional no Almanaque Brasileiro Garnier (1903-1914). Belo Horizonte: Editora UFMG, 2005, 253 p.

Num texto de 1890, Machado de Assis pediu licença aos bibliógrafos para revelar como se deu a invenção dos almanaques. Confidenciou às leitoras do Almanaque das Fluminenses que a idéia ocorrera ao Tempo, um velho de barbas brancas e coração ainda verde, ao ser recusado por Esperança, uma jovem com seus quinze anos. Para que a amada percebesse o esvaecer da mocidade, o Tempo "compôs um simples livro, seco, sem margens, sem nada; tão-somente os dias, as semanas, os meses e os anos. Um dia, ao amanhecer, toda a terra viu cair do céu uma chuva de folhetos". Não é difícil adivinhar a sequiência: Esperança, depois de passados muitos almanaques - assim que se con- tavam então os anos, explica Machado, - finalmente uniu-se ao Tempo e os almanaques, graças à sua colaboração, perderam a tristeza, "sempre acenando com alguma coisa que enchia a alma dos homens de paciência e vida. Assim as semanas, assim os meses, assim os anos. E choviam almanaques, muitos deles entremeados e adornados de figuras, de versos, de contos, de anedotas, de mil coisas recreativas. E choviam. E chovem. E hão de chover almanaques. O Tempo os imprime, Esperança os brocha; é toda a oficina da vida". ${ }^{1}$

A união entre a passagem inexorável do tempo e as renovadas esperanças que se depositam no início de cada novo ciclo podem, de fato, ser evocadas para explicar a origem desses folhetos, inicialmente articulados em torno do calendário, mas que se pluralizaram e assumiram diferentes sentidos e papéis desde o século XVI. Já as suas potencialidades como fonte de pesquisa 
para o historiador foram exploradas no trabalho de Eliana Dutra sobre o Almanaque Brasileiro Garnier (1903-1914), originalmente apresentado como um dos requisitos para o concurso de professor titular no Departamento de História da Universidade Federal de Minas Gerais.

Ao abrir o livro, o leitor não encontrará a tradicional folha de rosto, com título e dados de autoria e edição, antes será convidado a exercitar sua sensibilidade e mergulhar numa outra temporalidade, materializada num conjunto de imagens que o conduzem desde a fachada do imponente prédio da Livraria Garnier até as variadas páginas do seu almanaque. Estratégia que deleita, mas também intriga e alerta para a complexidade da empreitada. Para dar conta do desafio, a autora organizou a obra em quatro partes, compondo uma estrutura bem urdida, mas de geometria flexível, como convém a um objeto caleidoscópico e que permite múltiplas apreensões.

A primeira delas, Cartografia de um objeto, retraça as origens dos almanaques na Europa Moderna e pontua suas principais mutações no decorrer dos séculos, inserindo-os na história dos impressos, da leitura e dos leitores. Percurso que aporta no Rio de Janeiro do início do século XX, com suas livrarias, cafés e confeitarias, redaçóes de jornais e revistas, instituições culturais capazes de conferir poder e prestígio - a Academia Brasileira de Letras, o Colégio D. Pedro II, o Instituto Histórico e Geográfico Brasileiro -, sem esquecer as muitas oportunidades de estipêndio seguro para os que se engajavam nas repartições públicas. A Livraria Garnier e seu Almanaque Literário, Geográfico, Histórico e Enciclopédico são devidamente inseridos nesse circuito.

Da razão primeira e mais obvia para o lançamento da publicação, ou seja, difundir o nome e o espaço da livraria, divulgar os autores e obras que editava, o projeto ganha corpo e sentidos peculiares nas mãos dos editores Ramiz Galvão (19031906) e João Ribeiro (até 1914), homens de letras e luzes, que gozavam de prestígio e circulavam com desenvoltura no mundo da cultura. Credite-se a eles o fato de a publicação haver se tornado "instrumento de difusão e vulgarização de um projeto político e educativo, o de construção da nação republicana" (p. 27). Tal a tese que a autora enuncia e persegue ao longo do trabalho, tanto no perscrutar atento do conteúdo, quanto na descrição dos seus 
aspectos materiais, que informam sobre o público a que se destinava, sobre a abrangência da circulação, as mutações na distribuição dos conteúdos e sua hierarquia, que privilegiava os ensaios em detrimento do entretenimento e das diversões (charadas e advinhas), sem deixar de incorporar as "informaçōes variadas e conselhos úteis", tão características desse gênero. Escolha analítica que faz dos exemplares a um tempo fonte e objeto de estudo.

À cuidadosa cartografia seguese a segunda parte, Brasil com $S$ ou $Z$ ?, que se abre com a discussão da língua e literatura nacionais. Tema candente, como atestam as muitas matérias presentes no Almanaque, e que fornecem significativo panorama dos termos do debate no início do século XX. Entretanto, valeria destacar que a questão não era nova, mas arrastava os fios de uma tradição que pode ser remontada à independência e que ganhou novos contornos com o Romantismo. Sempre em pauta a afirmação nacional, que comportava a defesa de um idioma próprio, capaz de expressar o ser e o sentir brasileiros.

Reivindicava-se, agora como antes, não apenas autonomia diante das regras impostas por Portugal, mas também a necessidade de afir- mar um conjunto de realizações próprias, que atuassem como pólo capaz de aglutinar e explicar a nacionalidade. Daí o esforço, perceptível nas páginas do Almanaque Brasileiro Garnier, de constituir um cânone que englobasse poetas, romancistas, filósofos, historiadores, geógrafos, enfim, um rol de autores e livros capazes de explicar o Brasil e o significado de ser brasileiro. Eliana enfatiza como os responsáveis pelo periódico preocuparam-se em evidenciar a existência de uma herança cultural a ser compartilhada, e adverte para a natureza das escolhas e dos investimentos, o incensar de certas obras e autores.

A clara predominância de colaboradores consagrados e inseridos nas redes culturais dominantes não significou, contudo, impermeabilidade a outros discursos, como testemunha, por exemplo, a presença de artigos de Curvello de Mendonça, Elysio de Carvalho e Fábio Luz, que colocavam na ordem do dia questôes sociais e não poupavam críticas aos rumos seguidos pelo país, o que se constituía, como destaca a autora, numa plataforma capaz de agregar diferentes correntes da elite letrada.

Mas se havia uma herança comum a compartilhar e um cânone a difundir, a questão do estatuto das 
produçôes culturais populares e da fala rústica apresentavam-se com questóes a enfrentar. Com o correr do tempo, avultou nas páginas da publicação a importância dos estudos folclóricos, costumes, crenças, mitos e tradições, ao lado da miríade de variaçōes do falar regional, com seus vocábulos, locuçōes e expressões, aspectos que inquietavam uma intelectualidade que abraçava a idéia da nação homogênea e indivisa, tarefa postergada para um incerto amanhã.

As incertezas cresciam quando se tocava na questão da mestiçagem e seu corolário: a qualidade étnica dos habitantes. Tema incômodo e que foi menos aquinhoado nas páginas do Almanaque do que as representações acerca do território, suas decantadas riquezas e potencialidades, outro elemento-chave nas apreensões do país, contemplado na terceira parte da obra $O$ Brasil do futuro: o futuro habitat. Eliana Dutra enfatiza as apostas na integração efetiva de vastas extensōes de terras "à civilização", projeto que se considerava factível graças aos modernos meios de transportes e de comunicação. Tratava-se de vencer as selvas, ocupar os sertôes, inventariar riquezas e colocá-las a serviço do progresso da nação, programa que tinha em Rondon seu ícone mais acabado e devidamente saudado nas páginas da publicação. A insistência na definição das fronteiras e na constituição de um saber cartográfico seguro, a crença nas ciências, no poder da razão e no saber prático tinha como contrapartida a crítica ao formalismo inócuo do bacharel e à ineficiência dos políticos que comandavam o país. $\mathrm{O}$ orgulho era temperado com os exemplos de Oswaldo Cruz, Carlos Chagas, Clemente Ferreira e Emílio Ribas, que tornavam patente a capacidade de o Brasil integrar-se à produção científica internacional, apesar dos desmandos e mazelas da elite política, aferrada à monocultura.

A autora vai compondo um rico mosaico no qual otimismo e pessimismo se alternam nas páginas do Almanaque. Idas e vindas que também se expressaram na história da nação, objeto da última parte, $A$ história nas entrelinhas: um esboço final. A biografia da nacionalidade tem no passado seu material privilegiado: as datas a serem guardadas e rememoradas, os grandes episódios e personagens, as interpretaçóes consagradas, enfim, "o patrimônio nacional de lembranças materiais e simbólicas” (p. 232). No Garnier ocuparam lugar de especial destaque Capistrano de Abreu, João Ribeiro, 
Oliveira Lima e Rocha Pombo, responsáveis por consagrar a interpretação que apresentava a República como desdobramento natural da evolução do país, ainda que não fossem pequenas as desilusões e críticas desses "rebeldes literários" que, entretanto, pontificavam no mundo letrado do tempo.

$\mathrm{O}$ percurso delineado no $\mathrm{Al}$ manaque Garnier, um dos possíveis, como faz questão de destacar a historiadora, torna patente, por um lado, as múltiplas possibilidades abertas por fontes dessa natureza, seu conteúdo plural e complexo, aberto a muitas leituras e apreensões. Por outro, permite flagrar a atuação dos homens de letras nos anos iniciais da República, suas formas de agregação e sociabilidade, os espaços de consagração, as disputas e as aproximaçôes, o que colabora para dar outro estatuto aos chamados "pré-modernos", terminologia que já foi suficientemente questionada. Além disso, permite discernir os sonhos que a elite letrada acalentava, o lugar que se auto-atribuía na condução dos negócios do país, a disposição para ensinar e formar opiniōes, aspectos indissociáveis de projetos e propostas de cunho político. A língua e a literatura, a etnografia e o folclore, o espaço fí- sico e seus habitantes, o progresso e a civilização, os heróis, as datas cívicas, os mortos ilustres, a produção do ano que finda, as tarefas para o futuro: questóes insistentemente recolocadas, ainda que em outros contextos e por outros atores. Vale lembrar, portanto, a previsão de Machado: "E hão de chover almanaques. O Tempo os imprime, Esperança os brocha; é toda a oficina da vida”.

\section{Nota}

${ }^{1}$ ASSIS, Machado. Como se inventaram os almanaques. In: MEYER, Marlyse. Do Almanak aos Almanaques. São Paulo: Ateliê Editorial, 2001, pp. 25-28. 